OPEN ACCESS

Edited by:

Chris Wincup,

University College London,

United Kingdom

Reviewed by:

Andree Kurniawan,

University of Pelita Harapan, Indonesia

Sakir Ahmed,

Kalinga Institute of Medical Sciences

(KIMS), India

*Correspondence:

Lingli Dong

tjhdongl/@163.com

Jixin Zhong

Zhongjixin620@163.com

Specialty section:

This article was submitted to

Rheumatology,

a section of the journal

Frontiers in Medicine

Received: 15 June 2021

Accepted: 27 July 2021

Published: 19 August 2021

Citation:

Zhu Y, Zhong J and Dong L (2021)

Epidemiology and Clinical

Management of Rheumatic

Autoimmune Diseases in the

COVID-19 Pandemic: A Review.

Front. Med. 8:725226.

doi: 10.3389/fmed.2021.725226

\section{Epidemiology and Clinical Management of Rheumatic Autoimmune Diseases in the COVID-19 Pandemic: A Review}

\author{
Yingzi Zhu, Jixin Zhong* and Lingli Dong* \\ Department of Rheumatology and Immunology, Tongji Hospital, Tongji Medical College, Huazhong University of Science and \\ Technology, Wuhan, China
}

The coronavirus disease 2019 (COVID-19) has been in pandemic for more than 1 year, with serious negative effects produced worldwide. During this period, there have been a lot of studies on rheumatic autoimmune diseases (RADs) combined with COVID-19. The purpose of this study is to review and summarize these experiences. Pubmed, Web of science, Embase and the Cochrane library were searched from January 15, 2020 to July 15, 2021 using RADs and COVID-19 related keywords. Based on a comprehensive review of studies covering 16 countries, the prevalence of COVID-19 does not necessarily increase in RADs patients compared to the general population. In RADs population infected with COVID-19, a high proportion of female patients (54.44 95.2\%), elderly patients ( $\geq 50 y, 48 \sim 75.88 \%$ ), and patients with pre-existing comorbidities (respiratory, 4.8 60.4\%; endocrine, 8.52 44.72\%; cardiovascular, 15.7 64.73\%) were observed, although, this does not appear to have a decisive effect on disease severity. Many anti-rheumatic treatments have been extensively evaluated for their efficacy of treating COVID-19 in RADs patients, with TNF- $\alpha$ inhibitors and IL-6 receptor antagonist receiving more positive reviews. However, there is no conclusive information for most of the therapeutic regimens due to the lack of high-level evidence. Inflammatory markers or neutrophil-lymphocyte-ratio may be applied as indicators for clinical prognosis or therapeutic regimens adjustment. Thus, more research is still needed to address the prevalence, treatment, and clinical monitoring of RADs patients in COVID-19 pandemic.

Keywords: rheumatic autoimmune diseases, COVID-19, prevalence, treatment, laboratory indicator

\section{INTRODUCTION}

Since the end of 2019, the outbreak of coronavirus disease 2019 (COVID-19) has caused great consternation worldwide. Over the past year, rheumatologists have been actively working on the impact of COVID-19 on rheumatic autoimmune diseases (RADs) patients, and this topic is still on going. In the early stage of the pandemic, many studies suggested an increased incidence of COVID-19 in RADs patients (1-3). However, along with more clinical cases were included, different opinions have arisen. Meanwhile, a growing body of research has investigated the influencing factors of COVID-19 infection in RADs patients (4-6). Besides, the most important but controversial issue is the treatment for COVID-19 infection in RADs patients. Whether 
the presence of COVID-19 aggravates the existing RAD, or the underlying RAD increases the susceptibility of patients to COVID-19, establishing an effective therapeutic regime is a huge challenge. Several studies have suggested potential treatments, although, their benefits are limited to certain clinical conditions (7-10). It is therefore, particularly important to sum up the lessons learned during the pandemic.

Herein, we searched Pubmed, Web of science, Embase and the Cochrane library databases with related keywords, including "coronavirus disease 2019," "COVID-19," "SARS-CoV2," "rheumatic immune diseases," "rheumatoid arthritis," "systemic lupus erythematosus," "Sjogren Syndrome," "sicca," "Inflammatory myopathy," and "IgG4-related disease." The cutoff point for search is July 15, 2021. The inclusion criteria are: (1) The content of article involves the incidence, mortality or hospitalization rates of COVID-19 in RADs patients, the risk factors, treatment, and laboratory indicators; (2) Retrospective or prospective studies written in English, the full text of which is available online. The exclusion criteria are: (1) Short articles with incomplete information; (2) Single case report. After a detailed review, a series of epidemiological and clinical management characteristics of COVID-19 infection in RADs patients were obtained.

\section{EPIDEMIOLOGICAL FEATURES}

First, in terms of incidence, hospitalization rate and mortality, multiple studies were sorted out and presented in the order of cutoff date (Figure 1, data extracted from Table 1). The number of studies increased significantly in late March and throughout April, when the epidemic was going through a phase of surge in cases. Initially, as the place where the severe acute respiratory syndrome coronavirus 2 (SARS-CoV-2) was first detected, a multi-center retrospective study in Hubei province revealed a higher diagnostic rate of COVID-19 in RADs patients than in their family members without RADs (2). In Spain, data from seven hospitals showed that RADs patients manifested a significantly increased number of COVID-19 cases than that in the general population (3). Similarly, Italy, one of the European countries hardest hit by the outbreak, has a significantly higher prevalence of COVID-19 among the RADs population than in the general population (1). In England, a study involving 168,691 subjects adopted an index of age-standardized mortality rate (ASMR), and identified a higher risk of COVID-19 infection in RADs population (11). According to a nationwide cohort study from Denmark, RADs patients had an increased COVID19 associated hospitalization rate, compare to 4.5 million general population (12).

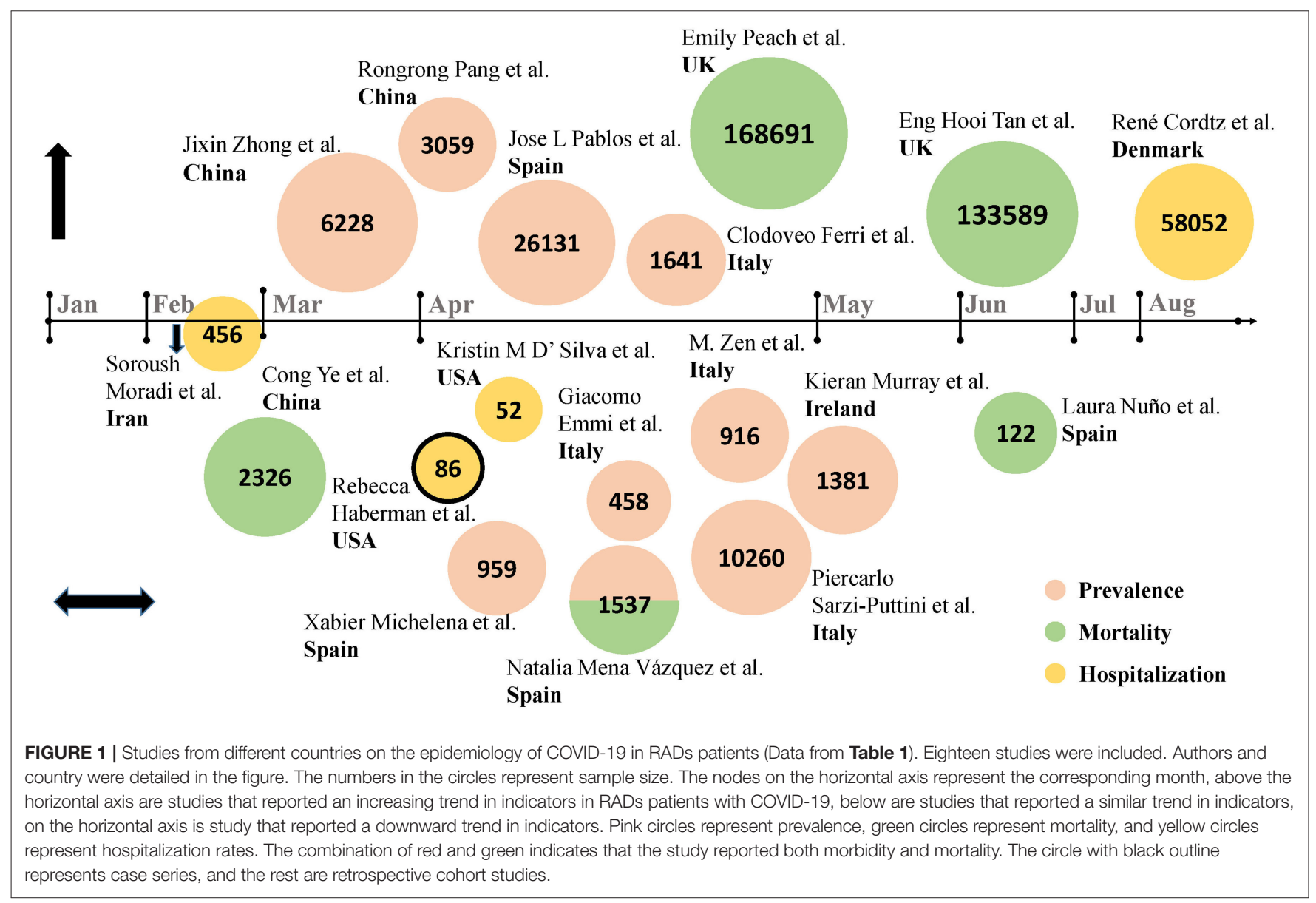


TABLE 1 | The incidence, hospitalization rates, and mortality of COVID-19 in RADs patients in studies from different nations (Shown in Figure 1).

\begin{tabular}{|c|c|c|c|c|c|c|c|}
\hline Author & Country & Study & Reference object & $N$ & Cutoff date & Outcomes & Ratio \\
\hline Moradi et al. & Iran & $\begin{array}{l}\text { Retrospective } \\
\text { cohort study }\end{array}$ & Non-rheumatic patients & 456 & $\begin{array}{l}\text { February 1, 2020-February 29, } \\
2020\end{array}$ & Lower prevalence & $3.6 \%$ vs. $8.7 \%$ \\
\hline Ye et al. & China & $\begin{array}{l}\text { Retrospective } \\
\text { cohort study }\end{array}$ & Non-rheumatic patients & 2,326 & January 13, 2020-March 15, 2020 & Similar mortality & $9.52 \%$ vs. $9.54 \%$ \\
\hline Zhong et al. & China & $\begin{array}{l}\text { Retrospective } \\
\text { cohort study }\end{array}$ & $\begin{array}{l}\text { Families without RADs } \\
\text { patient }\end{array}$ & 6,228 & $\begin{array}{l}\text { March 20, } 2020 \text { and March 30, } \\
2020\end{array}$ & Higher prevalence & $63 \%$ vs. $34 \%$ \\
\hline Haberman et al. & USA & Case series & General population & 86 & March 3, 2020-April 3, 2020 & Similar hospitalization rates & $16 \%$ vs. $26 \%$ \\
\hline D'Silva et al. & USA & $\begin{array}{l}\text { Retrospective } \\
\text { cohort study }\end{array}$ & Non-rheumatic patients & 52 & January 30, 2020-April 8,2020 & Similar hospitalization rates & $44 \%$ vs. $40 \%$ \\
\hline Pang et al. & China & $\begin{array}{l}\text { Retrospective } \\
\text { cohort study }\end{array}$ & General population & 3,059 & February 4, 2020-April 9, 2020 & Higher prevalence & $\begin{array}{l}\text { SLE: } 163 \text { per } 100,000 \text { vs. } \\
27-70 \text { per } 100,000, \text { RA: } 490 \\
\text { per } 100,000 \text { vs. } 280 \\
\text { per } 100,000\end{array}$ \\
\hline Michelena et al. & Spain & $\begin{array}{l}\text { Retrospective } \\
\text { cohort study }\end{array}$ & General population & 959 & March 26, 2020-April 10, 2020 & Similar prevalence & $0.48 \%$ vs. $0.58 \%$ \\
\hline Vázquez-Díaz et al. & Spain & $\begin{array}{l}\text { Retrospective } \\
\text { cohort study }\end{array}$ & General population & 1,537 & March 13, 2020-April 12, 2020 & $\begin{array}{l}\text { Similar prevalence and } \\
\text { mortality }\end{array}$ & $\begin{array}{l}\text { Prevalence: } 0.49 \% \\
\text { vs. } 0.5 \% \text {, mortality } 0.92 \% \\
\text { vs. } 2 \%\end{array}$ \\
\hline Emmi et al. & Italy & $\begin{array}{l}\text { Retrospective } \\
\text { cohort study }\end{array}$ & General population, & 458 & April 1, 2020-April 14, 2020 & Similar prevalence & $0.22 \%$ vs. $0.2 \%$ \\
\hline Pablos et al. & Spain & $\begin{array}{l}\text { Retrospective } \\
\text { cohort study }\end{array}$ & General population, & 26,131 & April 7, 2020-April 17, 2020 & Higher prevalence & $0.76 \%$ vs. $0.58 \%$ \\
\hline Sarzi-Puttini et al. & Italy & $\begin{array}{l}\text { Retrospective } \\
\text { cohort study }\end{array}$ & General population & 10,260 & March 15, 2020-April 23, 2020 & Similar prevalence & $0.65 \%$ (RADs patients) \\
\hline Ferri et al. & Italy & $\begin{array}{l}\text { Retrospective } \\
\text { cohort study }\end{array}$ & General population, & 1,641 & March 15, 2020-April 25, 2020 & Higher prevalence & $1.5 \%$ vs. $0.3 \%$ \\
\hline Zen et al. & Italy & $\begin{array}{l}\text { Retrospective } \\
\text { cohort study }\end{array}$ & General population & 916 & April 9, 2020-April 25, 2020 & Similar prevalence & $0.21 \%$ (RADs patients) \\
\hline Peach et al. & UK & $\begin{array}{l}\text { Retrospective } \\
\text { cohort study }\end{array}$ & General population, & 168,691 & March 1, 2020-April 30, 2020 & $\begin{array}{l}\text { Higher age-standardized } \\
\text { mortality }\end{array}$ & 1.38 fold (\% NA) \\
\hline Murray et al. & Ireland & $\begin{array}{l}\text { Retrospective } \\
\text { cohort study }\end{array}$ & General population & 1,381 & April 28, 2020-May 5, 2020 & Similar prevalence & $0.46 \%$ vs. $0.44 \%$ \\
\hline Tan et al. & UK & $\begin{array}{l}\text { Retrospective } \\
\text { cohort study }\end{array}$ & $\begin{array}{l}\text { RADs patients during } \\
\text { influenza infection }\end{array}$ & 133,589 & January-June, 2020 & Higher 30-day mortality & $\begin{array}{l}\text { ( } 2.2 \% \text { to } 4.3 \%) \text { vs. }(6.3 \% \\
\text { to } 24.6 \%)\end{array}$ \\
\hline Nuño et al. & Spain & $\begin{array}{l}\text { Retrospective } \\
\text { cohort study }\end{array}$ & General population & 122 & February 25, 2020-June 8, 2020 & Similar mortality & NA \\
\hline \multirow[t]{2}{*}{ Cordtz et al. } & Denmark & $\begin{array}{l}\text { Retrospective } \\
\text { cohort study }\end{array}$ & General population & 58,052 & March 1, 2020-August 12, 2020 & Higher hospitalization rates & HR 1.46 \\
\hline & & & & & & & $95 \%$ Cl 1.15-1.86 (\% NA) \\
\hline
\end{tabular}

RADs, rheumatic autoimmune diseases; Ratio, \% of COVID-19 infected RADs patient versus (vs.) \% of COVID-19 infected reference population or hazard ratio (HR); N, sample size; SLE, Systemic lupus erythematosus; RA, Rheumatoid arthritis; Cl, confidence interval; NA, data not avaliable. 
However, studies have also shown that the diagnostic rate of SARS-CoV-2 in RADs patients does not necessarily increase, at least, they are less likely to develop into severe cases (13, 14). By analyzing the 2-month electronic medical records of Huoshenshan Hospital in Wuhan, China, a study showed the admission rate of ICU, hospital stays and mortality of COVID-19 in RADs patients were similar to the non-RADs patients (15), and these points have been supported by other cohort studies (1618). It has even been reported that the prevalence of COVID-19 in RADs patients is lower than that of randomly selected nonRADs patients (19), which is based on the explanation that RADs patients are more consciously following the rules of epidemic prevention and control.

The proportion of each RAD in COVID-19 infected patients also varied. COVID-19 symptoms have been reported to be closely associated with rheumatoid arthritis (RA), vasculitis, spondyloarthrosis (SpA), psoriatic arthritis (PsA), and sicca syndrome $(12,13,20,21)$. Although, it has been suggested that the incidence of COVID-19 is higher in connective tissue diseases (CTDs) patients than those with inflammatory arthritis (IA) (1), we found that in most studies $(4,18,22-25)$, RA accounts for a significantly higher proportion, with a range from 3.9 to $40.65 \%$ (Table 2). In addition to cases of COVID-19 infection in RADs patients, COVID-19 also appears to promote the development of RADs. During the COVID-19 outbreak, the prevalence of dermatomyositis was witnessed surge in India (26). Regarding the inconsistent prevalence of COVID-19 among distinct RADs, a study speculated that for certain RADs, the activity of underlying immune pathways were not completely the same (27), which results in the diverse involvement of RAD in the pathogenesis. Besides, this trend is also associated with the incidence of specific RADs themselves, thus it cannot be concluded that the prevalence of these diseases in COVID-19 is elevated.

Practically, these views are in dynamic change, and a number of meta-analyses and systematic reviews are in progress (International prospective register of systematic reviews, PROSPERO). In the second half of 2020, the COVID-19 pandemic has rebounded, which will certainly influence the evolution of disease.

\section{INFLUENCING FACTORS OF RADS COMPLICATED WITH COVID-19}

As with any disease, multiple factors can influence the infection and evolution of COVID-19 in RADs patients. Several factors that may be closely related to the disease were summarized from the existing studies.

\section{Age and Gender}

It is generally accepted that patients diagnosed with COVID19 tend to be elderly $(5,20,28)$. Aging was seen as a factor independently related to hospital admission in RADs patients infected with SARS-CoV-2 (4). In many studies (5, 20, 22, 23, $25,28,29)$, cases over the age of 50 often account for more than half of all cases (Figure 2). But what is noteworthy is that the incidence of COVID-19 skewed toward a younger crowd gradually. Upon COVID-19 infection, age-specific mortality rates in RADs patients notably increased from the age of 35 years old, while in the uninfected population, this indicator began from the age of 55 years old (11).

Male and female patients behave differently in COVID-19 outbreak. The majority of RADs patients infected with COVID19 were female $(4,5,15,18,20,22,23,25,28-32)$, generally exceeding $60 \%$, with an average of $70.86 \%$ (Figure 2 ). The overall mortality during COVID-19 development was higher in female RADs patients (11), which is different from the situation in nonRAD population that male accounts for a greater proportion. However, there were also other studies reporting that male could be an independent factor associated with the severity of COVID19 , for male RADs patients may have worse prognosis, higher hospitalization rate and risk of severe pneumonia $(22,28)$.

\section{Comorbidities}

More unfavorable effects tend to occur when RADs patients suffer from comorbidities, especially under the condition of COVID-19 infection. In view of this, during the COVID-19 epidemic, rheumatologists paid considerable attention to the adverse effects of comorbidities on RADs patients. Overall, after data integration of 14 articles retrieved $(4,5,15,18,20,22-$ $25,28-32)$, the most common comorbidities in RADs patients infected with COVID-19 were cardiovascular diseases (37.34\%), endocrine diseases (25.02\%) and respiratory diseases $(23.45 \%)$ (Figure 2), which were mainly attributed to hypertension, diabetes, chronic obstructive pulmonary disease and asthma, respectively. Renal diseases and hepatic diseases also account for a small proportion (11.57 and $6.14 \%$, respectively). In the COVID-19 pandemic, the number of comorbidities are strongly associated with the general condition of patients, comprehensive recognition of the complexity of the diseases is of great significance. RADs patients with coexisting comorbidities should be classified for treatment in order to develop an ideal treatment plan.

\section{Race and Geography}

Among different races, due to the influence of genetics, survival environment or life styles, slight or apparent discrepancies exist in the disease manifestations. The proportion of RADs patients from different ethnic groups varies in the COVID-19 pandemic $(30,31,33,34)$. In a race-focused study on 1,324 patients, by using multivariable models, researchers compared the clinical manifestations among African American, Latinx, Asian, and White patients. Results showed that RADs patients of the three former races have higher COVID-19 associated hospitalization rates than White patients, and the need for ventilator support is greater among Latinx patients, but no statistical difference in the mortality of COVID-19 was observed (35).

Geographical factors may affect the spread and evolution of COVID-19. As we mentioned in the epidemiological features section, studies from different countries or regions revealed disparities in morbidity, hospitalization rate or mortality of COVID-19 in RADs patients $(1-3,13,14,36)$, and ultimately affect the overall management and prevention of the COVID19 pandemic. Mehta et al. (37) noted geographic differences in 
TABLE 2 | The proportion of different RADs in COVID-19 infection.

\begin{tabular}{|c|c|c|c|c|c|c|c|c|c|c|}
\hline Author & Country & $N$ & RA (\%) & SpA (\%) & $\begin{array}{c}\text { CTD (SLE } \\
\text { included) } \\
(\%)\end{array}$ & PsA (\%) & $\begin{array}{c}\text { Vasculitis } \\
(\%)\end{array}$ & $\begin{array}{c}\text { Polymyalgia } \\
\text { rheumatica } \\
\text { (\%) }\end{array}$ & SS (\%) & $\begin{array}{c}\text { Miscellaneous } \\
(\%)\end{array}$ \\
\hline Nuño et al. & Spain & 122 & 33.6 & 19.7 & 10.7 & 10.7 & NA & NA & NA & 25.4 \\
\hline Freites Nuñez et al. & Spain & 123 & 40.65 & 14.63 & 6.5 & 4.88 & 1.63 & NA & 7.32 & 4.88 \\
\hline Scirè et al. & Italy & 232 & 34.1 & 26.3 & 21.1 & NA & 11.2 & NA & NA & NA \\
\hline Tan et al. & UK & 133,589 & $3.9-18.9$ & NA & NA & $3.5-32.5$ & $3.3-17.6$ & 4.88 & NA & NA \\
\hline Montero et al. & Spain & 62 & 32 & 26 & 36 & NA & NA & NA & NA & NA \\
\hline Galarza-Delgado et al. & Mexico & 38 & 39.47 & 8.5 & 34.21 & 6.9 & NA & NA & NA & NA \\
\hline Gianfrancesco et al. & Australia & 600 & 38 & 8 & 14 & 12 & 7 & 2 & 5 & 5 \\
\hline
\end{tabular}

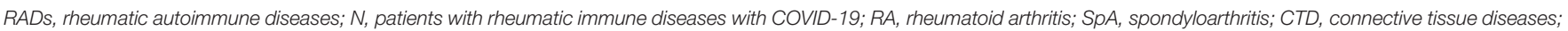
SLE, systemic lupus erythematosus; PSA, psoriatic arthritis; SS, Sjogren Syndrome; NA, data not avaliable.

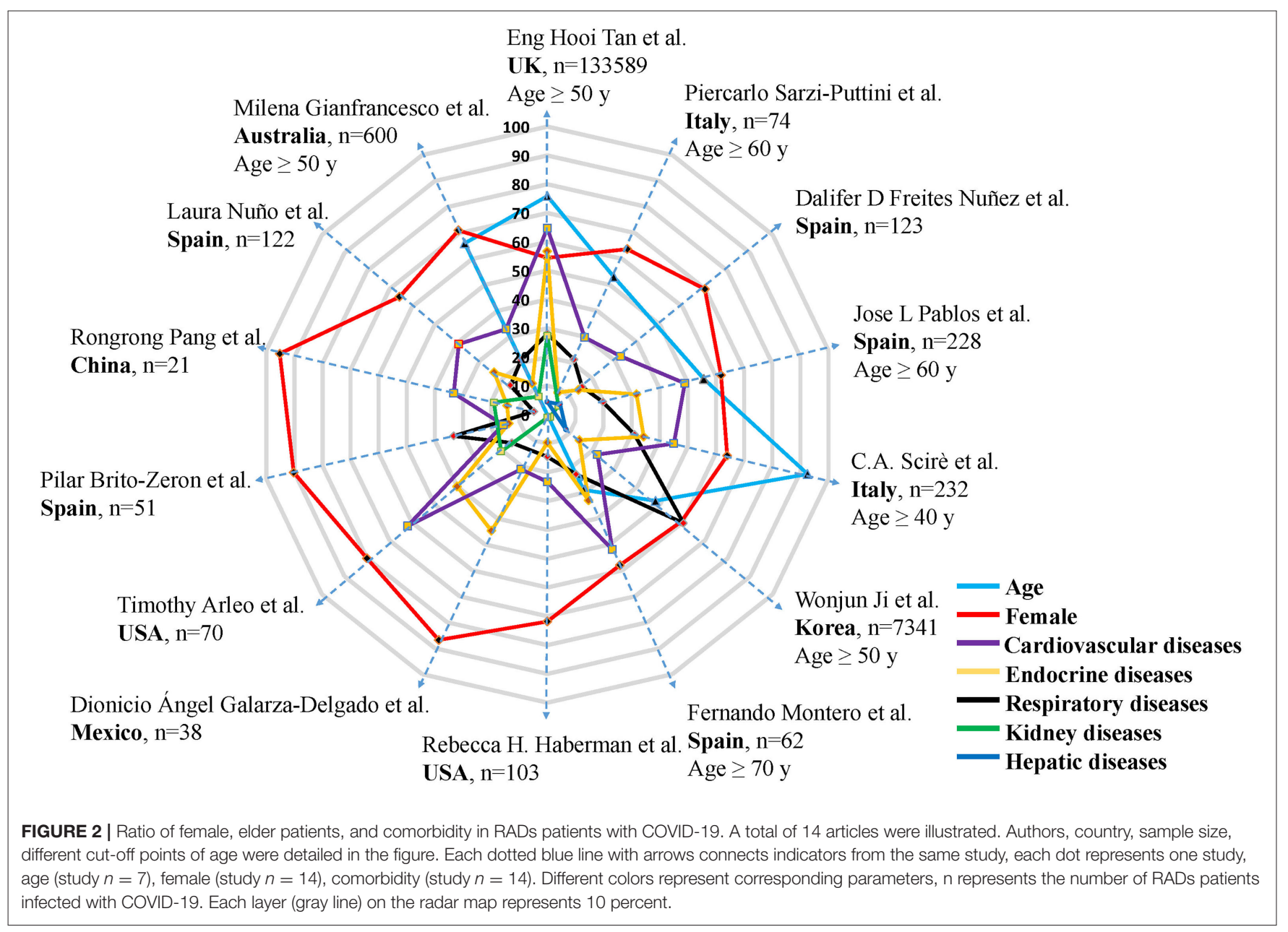

cognition on disease nursing, therapy adjustment and follow-up, especially in areas with a high COVID-19 incidence.

\section{TREATMENTS}

Formulating an effective therapeutic regimen is central to combat COVID-19, rheumatologists have made many attempts to address this problem in RADs patients. Amongst, the common drugs mainly include glucocorticoid, conventional disease modifying anti-rheumatic drugs (csDMARDs), antimalarial drugs and biologic or targeted synthetic disease-modifying antirheumatic drugs (b/tsDMARDs). Either maintenance treatment prior to diagnosis of COVID-19 or treatment initiated after diagnosis, these drugs act on COVID-19 infected RADs patients 
based on different pharmacological mechanisms, and have their own merits or limitations.

\section{Corticosteroids}

The role of glucocorticoids in the treatment of rheumatic diseases is of landmark significance, while its role in rheumatic patients with COVID-19 infection is controversial. Results from the retrospective $(n=600)$ or prospective $(n=103)$ study found that prednisone use caused an increased hospitalization rates, especially when the dose of prednisone exceeded $10 \mathrm{mg}$ per day, and disease activity was not significantly associated with glucocorticoid-induced hospitalization rates. Compared with non-hospitalized patients, the proportion of SLE and vasculitis was higher in hospitalized patients, while the proportion of psoriatic arthritis and ankylosing spondylitis was lower (25, 38). Another study has also confirmed the dose-dependent effect of glucocorticoid on positive diagnostic rate as well as COVID-19 associated hospitalization rates (7). In addition, Nuño et al. (18) found an increased mortality after glucocorticoid treatment in RADs patients. What is noteworthy is that although, glucocorticoids use seems to be associated with an increased risk of COVID-19 infection, rheumatologists suggest that it is reasonable to reduce glucocorticoids gradually to 5-7.5 mg/day, discontinuation of glucocorticoids during the pandemic is not recommended (10). After all, in single case reports, improvements of renal, respiratory, neurological and liver function in systemic lupus erythematosus (SLE) or SLE-like patients infected with COVID-19 were observed $(39,40)$.

\section{Conventional Synthetic Disease-Modifying Anti-rheumatic Drugs}

With multiple categories and unique mechanism, csDMARDs play a key role in the treatment for RADs. Taking csDMARDs has been reported to benefit clinical outcomes by reducing the risk of COVID-19 infection, the protective effect of leflunomide on the cytokine storm emerging in severe COVID-19 cases was also proposed $(19,41)$. In addition, RADs patients treated with cyclosporine A and tacrolimus during COVID-19 infection had a relatively mild clinical course and a reduced susceptibility to reinfection (42). A meta-analysis involving eight studies showed that colchicine reduced the mortality of COVID-19 patients and the number of severe cases, which could be good news for gout sufferers (43).

However, in the vast majority of cases, the effect of csDMARDs on COVID-19 infection was neutral. A joint multinational, retrospective study of Asia, European and North America utilized network data and found no extra risk of severe events on a 30-day combined use of hydroxychloroquine (HCQ) and sulfasalazine (44). Likewise, in RADs patients treated with csDMARDs alone (methotrexate or cyclosporine) or in conjunction with biological agents or Janus Kinase inhibitors, no influence on the susceptibility to COVID-19 or hospitalization rate was observed $(25,45)$. Based on the neutral roles of csDMARDs, tapering or even discontinue of csDMARDs are suggestive strategies to recover anti-infection immunity in severe cases, which may help eliminate the virus rapidly (46).

\section{Antimalarial Drugs}

Based on the long history of safe and effective use in RADs (47), antimalarial drugs have received unprecedented attention in fighting against COVID-19. As one of the typical antimalarial drugs, the role of HCQ in RADs with COVID-19 was studied in many countries and regions. In a previously mentioned study, RADs patients who had taken HCQ were less susceptibility to COVID-19 compared to patients who had taken other csDMARDs (OR 0.09, $p=0.044$ ) (2). And another retrospective study suggested that long-term treatment of HCQ in RADs patients (at least $2 \mathrm{~g} /$ month) can protect against COVID-19 infection (48).

However, there were also studies have proposed the conservative effect of HCQ in treatment for RADs patients infected with COVID-19. Among SLE patients, whether treated with HCQ or without, the infection of SARS-CoV-2 and clinical symptoms were comparable, implying that chronic HCQ therapy did not have satisfactory results in inhibiting COVID19 progression (7). Besides, past exposure to HCQ also did not prevent disease progression (49), RADs patients treated with HCQ may still be affected by COVID-19 in severe cases $(40,49-$ 51).

In general, there are a lot of controversies about HCQ efficacy in rheumatism associated COVID-19. Nonetheless, during COVID-19 epidemic, HCQ is proposed to be the only treatment that is likely to increase survival in SLE patients, and it is not advisable to discard the HCQ-included regimen. American College of Rheumatology's guideline suggests that it is reasonable to adjust HCQ dosing intervals or dosage according to the practical situations (52).

The incidence of HCQ associated adverse events (AEs) was affected by the length of hospital stay (53). The incidence of HCQ related AEs was not significant after 1 week of short-term use, whereas, increased after $2-4$ weeks of treatment $(54,55)$. Notably, the majority of AEs tends to occur with the first cumulative dose of $1 \mathrm{~g}$, after which the frequency of AEs declined (56).

\section{Biologic Or Targeted Synthetic Disease-Modifying Anti-rheumatic Drugs}

Given their broad molecular mechanisms, b/tsDMARDs may be potentially useful in alleviating inflammatory cytokine storm under COVID-19 attack (57). Different b/tsDMARDs affect the COVID-19 course differently. Compared with RADs patients treated with CD20 monoclonal antibody rituximab or IL-17A antagonist secukinumab, patients receiving tumor necrosis factor (TNF) inhibitors etanercept and adamuzumab or IL-6 receptor antagonist tocilizumab may experience a relatively mild course (9, 18, 58). In addition, the effects of TNF inhibitors and tocilizumab on clinical epidemiology have also been reported. Patients receiving adalimumab or infliximab treatment had a reduced risk of COVID-19 infection (19), and monotherapy of TNF-inhibitor prior to COVID-19 infection may reduce the COVID-19-related hospitalization or severity $(12,25,31,36)$. Treatment of tocilizumab has been proven to ensure stability of vascular permeability and myocardial function in RA patients 
infected with COVID-19 (59, 60), and also reduce the COVID19 associated mortality and levels of inflammatory indicators $(61,62)$.

Nevertheless, many studies have shown the ineffectiveness, or even negative effects of b/tSDMARDs in the COVID-19 pandemic. In a clinical observation of small sample size $(n=21)$, in patients with COVID-19 associated pneumonia, tocilizumab administration showed no positive effect on ICU admission or 7-day mortality rate, compared to those who did not use tocilizumab (63), and patients treated with rituximab had a relatively higher hospitalization rate (64).

For the treatment after the infection of COVID-19, in general, the majority of studies have reported that these treatments just have a neutral effect on RADs patients, the mortality or hospitalization rate of patients have not been particularly affected. In contrast to the possible positive effect of maintenance treatment before diagnosis of COVID-19, the use of biologic agents after COVID-19 diagnosis did not stop the disease from progressing (Table 3).

To sum up, no definitely positive or negative effect of any therapy can be totally determined, personalized medicine, and flexible adjustment are of outstanding importance.

\section{APPLICABLE LABORATORY INDICATORS}

During the evolution of COVID-19 infection, several laboratory indicators fluctuate due to the immune system imbalance caused by viral attack and the inherent immune disorders in RADs patients, some of which may be helpful in monitoring disease fluctuations. At present, the indicators specific for RADs with COVID-19 infection are inconclusive. Here, we enumerate some indicators that may be useful for clinical guidance.

Typically, as a series of immune disorders mediated by inflammatory mechanisms, RADs usually exhibit alterations in inflammatory markers. Tan $\mathrm{C}$ et al. found that the significant increase of C-reactive protein (CRP) may be a potential early predictor for the severity of COVID-19, for CRP changes precede the imaging findings (65). And cohort studies reported a significant correlation between poor prognosis and elevated serum ferritin, IL- 6 and procalcitonin $(15,66,67)$. In their metaanalysis, Hariyanto et al. (68) summarized the predictive roles of increased procalcitonin $(\geq 0.065 \mathrm{ng} / \mathrm{ml})$, CRP $(\geq 33.55 \mathrm{mg} / \mathrm{L})$, Ddimer $(\geq 0.635 \mu \mathrm{g} / \mathrm{L}), \mathrm{LDH}(\geq 263.5 \mathrm{U} / \mathrm{L})$ and decreased albumin $(\leq 38.85 \mathrm{~g} / \mathrm{L})$ in the clinical prognosis of COVID-19 (68).

In addition, the proportion or number of immune cells can also be altered. Severe COVID-19 infected cases are more likely to have decreased lymphocytes, increased leukocytes counts and thus elevated neutrophil-lymphocyte-ratio (NLR). Moreover, either the percentage or the number of helper, memory helper and regulatory $\mathrm{T}$ cells can be reduced in RADs patients infected with COVID-19 (69). Unfortunately, although, a receiver operating curve (ROC) analysis of data from Hasan Sadikin Lupus Registry (HSLR) suggested an optimal cut-off of NLR at 2.94 can obtain a satisfactory sensitivity and specificity of the survival of SLE patient (70), there is no ideal cut-off of NLR can be applied to monitor COVID-19 condition yet.
It is worth noting that RADs related autoantibodies may present among non-RAD severe COVID-19 cases (Table 4). Lupus anticoagulants are common in COVID-19 patients (71, 72), and a level of over $15 \mathrm{U} / \mathrm{mL}$ of a-CL $\operatorname{IgG}$ may be an independent risk factor for the severity of COVID-19 (73). The ANAs-positive rate in COVID-19 patients can be as high as $50 \%$, although, there was no significant difference in ANAs level between severe and mild patients (74-76). Elevated anti-SSA/Ro antibodies can be observed in COVID-19 patients with severe respiratory failure (77).

In summary, the sensitivity and specificity of clinical indicators may be affected by comorbidities, and a single indicator often reflects physiological changes in multiple organ functions. Because of the special practicability, there is an urgent need to find indicators with high specificity to monitor disease state.

\section{DISCUSSION}

In this study, we proposed some reflections on the dilemma faced by RADs patients in the COVID-19 epidemic by reading up on the viewpoints from a large number of studies. By integrating data on epidemiology, influencing factors, treatments and laboratory indicators, we found that the prevalence of COVID-19 in RADs patients did not necessarily increase, female and elderly patients account for a large proportion of RADs patients infected with COVID-19. Treatment with b/tsDMARDs TNF-inhibitors or tocilizumab may have a clinical benefit in reducing COVID-19 related hospitalization or mortality. Inflammatory markers such as procalcitonin, CRP, D-dimer, LDH, IL-6, or NLR may be useful in the surveillance of COVID-19 infection.

Objectively speaking, the incidence of COVID-19 in a region or country is closely related to the local capacity for disease control and awareness of the disease among the public. Behavioral factors, including wearing masks, improving sanitation, or even stopping the use of immunosuppressants without a doctor's instruction, may have influenced the researchers' assessment of true infection rates. In particular, as the COVID-19 vaccine becomes available, how well the vaccine supply matches the local population, as well as the coverage of the vaccinated population, will affect the global progress of COVID-19. Identification of the influencing factors is a tricky issue because it is difficult to standardize factors in different studies. In fact, in the overall COVID-19 population, males are more common than females (78), and in the absence of COVID19 , females usually make up a larger proportion in most RADs, thus, it is difficult to determine the true gender-related incidence of COVID-19 in RADs patients without the information about gender composition in local RAD population.

Moreover, flexible management of treatment regimens in response to COVID-19 is critical for rheumatologists. Regarding the administration of glucocorticoids, since there has been a dose-dependent effect on disease progression in RADs patients infected with COVID-19, glucocorticoids should always be administrated prudently. For the clinical efficacy of csDMARDs, both positive and negative effects possess their own evidence. 
TABLE 3 | Treatments on RADs patients with COVID-19.

\begin{tabular}{|c|c|c|c|c|c|c|c|c|c|c|c|c|}
\hline \multirow[t]{2}{*}{ Author } & \multirow[t]{2}{*}{ Country } & \multirow[t]{2}{*}{ Study } & \multirow[t]{2}{*}{$N$} & \multirow[t]{2}{*}{ Cut-off Date } & \multicolumn{2}{|c|}{ Glucocorticoid } & \multicolumn{2}{|c|}{ csDMARDs } & \multicolumn{2}{|c|}{ Antimalarial } & \multicolumn{2}{|c|}{ t/sDMARDs } \\
\hline & & & & & $n$ & Efficacy & $n$ & Efficacy & $n$ & Efficacy & $n$ & Efficacy \\
\hline Yousaf et al. & USA & $\begin{array}{l}\text { Retrospective } \\
\text { cohort study }\end{array}$ & 6,548 & $\begin{array}{l}\text { January 20, } \\
2020-J u n e ~ 11, \\
2020\end{array}$ & & NA & 98 & Neutral & & NA & 58 & Neutral \\
\hline Mathian et al. & France & Case series & 17 & $\begin{array}{l}\text { March 29, } \\
2020-A p r i l ~ 6, \\
2020\end{array}$ & & NA & & NA & 17 & \multicolumn{2}{|c|}{ Can not stop the progression to severity } & NA \\
\hline Teh et al. & Malaysia & Case series & 5 & March 1, 2020 & & NA & & NA & 5 & \multicolumn{3}{|c|}{ Severe course needing aggressive therapy NA } \\
\hline Price et al. & USA & $\begin{array}{l}\text { Retrospective } \\
\text { cohort study }\end{array}$ & 239 & $\begin{array}{l}\text { March 10, } \\
2020-A p r i l ~ 21, \\
2020\end{array}$ & & NA & & NA & & NA & 153 & $\begin{array}{l}\text { Survival } \\
\text { improved }\end{array}$ \\
\hline Freites Nuñez et al. & Spain & $\begin{array}{l}\text { Prospective } \\
\text { cohort study }\end{array}$ & 123 & $\begin{array}{l}\text { March 1, } \\
2020-\text { April 24, } \\
2020\end{array}$ & 61 & Neutral & 77 & Neutral & 27 & Neutral & 17 & Risk reduced \\
\hline Galarza-Delgado et al. & México & Case series & 38 & $\begin{array}{l}\text { July 2020-August } \\
2020\end{array}$ & & NA & 28 & Neutral & 16 & Neutral & & NA \\
\hline Loarce-Martos et al. & Spain & $\begin{array}{l}\text { Retrospective } \\
\text { cohort study }\end{array}$ & 13 & $\begin{array}{l}\text { February 1, } \\
2020-\text { May 26, } \\
2020\end{array}$ & & NA & & NA & & NA & 13 & $\begin{array}{l}\text { Severe cases } \\
\text { increased }\end{array}$ \\
\hline Nuño et al. & Spain & $\begin{array}{l}\text { Retrospective } \\
\text { cohort study }\end{array}$ & 122 & $\begin{array}{l}\text { February 25, } \\
2020-J u n e ~ \\
2020\end{array}$ & 47 & $\begin{array}{l}\text { Mortality } \\
\text { increased }\end{array}$ & 47 & $\begin{array}{l}\text { Hospitalization } \\
\text { rates increased }\end{array}$ & 25 & Neutral & 20 & $\begin{array}{l}\text { Hospitalization } \\
\text { rates increased }\end{array}$ \\
\hline Cavagna et al. & Italy & $\begin{array}{l}\text { Retrospective } \\
\text { cohort study }\end{array}$ & 53 & $\begin{array}{l}\text { Febrary 2020-April } \\
28,2020\end{array}$ & & NA & 53 & Neutral & & NA & & NA \\
\hline Zurita et al. & Ecuador & Case series & 5 & $\begin{array}{l}\text { March 3, } \\
2020-\text { May 21, } \\
2020\end{array}$ & & NA & & NA & 5 & Neutral & & NA \\
\hline Colaneri et al. & Italy & $\begin{array}{l}\text { Retrospective } \\
\text { cohort study }\end{array}$ & 112 & $\begin{array}{l}\text { March 14, } \\
2020-\text { March 27, } \\
2020\end{array}$ & & NA & & NA & & NA & 21 & Neutral \\
\hline Haberman et al. & USA & $\begin{array}{l}\text { Prospective } \\
\text { cohort study }\end{array}$ & 103 & $\begin{array}{l}\text { March 3, } \\
\text { 2020-May 4, } 2020\end{array}$ & 13 & Hospitaliza & rates increased & NA & & NA & 73 & Neutral \\
\hline Cordtz et al. & Denmark & $\begin{array}{l}\text { Retrospective } \\
\text { cohort study }\end{array}$ & 138 & $\begin{array}{l}\text { March 1, } \\
2020 \text {-August 12, } \\
2020\end{array}$ & & Neutral & & NA & & Neutral & & Neutral \\
\hline Jung et al. & Korea & $\begin{array}{l}\text { Retrospective } \\
\text { cohort study }\end{array}$ & 2,066 & Before May, 2020 & & NA & & NA & 649 & Neutral & & NA \\
\hline Arleo et al. & USA & $\begin{array}{l}\text { Retrospective } \\
\text { cohort study }\end{array}$ & 70 & $\begin{array}{l}\text { February } 1, \\
2020-J u l y 31, \\
2020\end{array}$ & & NA & 13 & Hospitalization r & ates increased I & NA & 10 & $\begin{array}{l}\text { Hospitalization } \\
\text { rates decreased }\end{array}$ \\
\hline
\end{tabular}

The studies presented mainly includes treatment regimens after COVID-19 diagnosis. N, numbers of RADs patients infected with COVID-19; $n$, the number of people who received treatment; NA, data not available; Neutral, there is no particularly beneficial or harmful clinical effect. 
TABLE 4 | Autoantibodies are present in patients with non-rheumatic diseases infected with COVID-19.

\begin{tabular}{|c|c|c|c|c|c|c|c|c|}
\hline Author & Country & $\mathbf{N}$ & Study & Cutoff date & Female (\%) & $\begin{array}{l}\text { Age (mean } \pm \\
\text { SD)/median } \\
\text { (range) }\end{array}$ & Autoantibody & $\begin{array}{c}\% \text { of } \\
\text { patients }\end{array}$ \\
\hline Reyes Gil et al. & USA & 68 & $\begin{array}{l}\text { Retrospective } \\
\text { cohort study }\end{array}$ & $\begin{array}{l}\text { March 1, 2020-April } \\
30,2020\end{array}$ & 49.65 & $57.61 \pm 17.02$ & Lupus anticoagulant & 44 \\
\hline \multirow[t]{2}{*}{ Gatto et al. } & Italy & 122 & $\begin{array}{l}\text { Retrospective } \\
\text { cohort study }\end{array}$ & $\begin{array}{l}\text { January 15, 2020-April } \\
30,2020\end{array}$ & 50.8 & $54.3 \pm 19.3$ & $\begin{array}{l}\text { Anti cardiolipin (a-CL) } \\
\text { lgG/lgM }\end{array}$ & $13.4 / 2.7$ \\
\hline & & & & & & & $\begin{array}{l}\text { Anti-beta } 2 \\
\text { glycoprotein I ( } \beta 2 \mathrm{GPI}) \\
\text { lgG/lgM }\end{array}$ & $6.3 / 7.1$ \\
\hline \multirow[t]{3}{*}{ Pascolini et al. } & Italy & 33 & $\begin{array}{l}\text { Prospectively } \\
\text { cohort study }\end{array}$ & $\begin{array}{l}\text { March 30, 2020-May } \\
10,2020\end{array}$ & 48.4 & $70(22-90)$ & $\begin{array}{l}\text { Antinuclear antibodies } \\
\text { (ANAs) }\end{array}$ & 33 \\
\hline & & & & & & & a-CL lgG and/or lgM & 24 \\
\hline & & & & & & & $\begin{array}{l}\text { Anti- } \beta 2 \text {-glycoprotein } \\
\text { antibodies IgG and/or } \\
\text { lgM }\end{array}$ & 9 \\
\hline Zhang et al. & China & 19 & $\begin{array}{l}\text { Retrospective } \\
\text { cohort study }\end{array}$ & $\begin{array}{l}\text { February 23, } \\
\text { 2020-March 31, } 2020\end{array}$ & 47.4 & $65(60-70)$ & $\begin{array}{l}\text { Anti-phospholipid } \\
\text { antibodies }\end{array}$ & 52.6 \\
\hline Bowles et al. & UK & 35 & Case series & Before May, 2020 & 31 & $56.6(18.6-83.4)$ & Lupus anticoagulant & 91 \\
\hline Amezcua-Guerra et al. & Mexico & 21 & Case series & $\begin{array}{l}\text { April 12, 2020-April 19, } \\
2020\end{array}$ & 57 & $62(54-67)$ & $\begin{array}{l}\text { Antiphospholipid } \\
\text { antibodies }\end{array}$ & 57.14 \\
\hline Bertin et al. & France & 56 & $\begin{array}{l}\text { Retrospective } \\
\text { cohort study }\end{array}$ & NA & 50 & $66.6(17.8)$ & a-CL lgG/lgM & 100 \\
\hline \multirow[t]{3}{*}{ Zhou et al. } & China & 21 & Retrospective & January 28, & 38 & $66.10 \pm 13.94$ & Anti-SSA/Ro antibodies & 20 \\
\hline & & & cohort study & 2020-March 2, 2020 & & & $\begin{array}{l}\text { Anti-60 kDa SSA/Ro } \\
\text { antibodies }\end{array}$ & 25 \\
\hline & & & & & & & ANAs & 50 \\
\hline \multirow{6}{*}{$\begin{array}{l}\text { Vlachoyiannopoulos } \\
\text { et al. }\end{array}$} & Greece & 29 & Case series & Before May & 27.6 & $64.2(43-85)$ & ANAs & 34.5 \\
\hline & & & & & & & $\mathrm{p}$-ANCA & 6.9 \\
\hline & & & & & & & C-ANCA & 6.9 \\
\hline & & & & & & & $\mathrm{a}-\mathrm{CL}$ & 24.1 \\
\hline & & & & & & & Anti- $\beta 2 \mathrm{GPI}$ antibodies & 34.5 \\
\hline & & & & & & & $\begin{array}{l}\text { Anti-cyclic citrullinated } \\
\text { peptide (CCP) } \\
\text { antibodies }\end{array}$ & 3.5 \\
\hline Fujii et al. & Japan & 2 & Case series & Before August & & & Anti-SSA/Ro antibodies & 2 \\
\hline
\end{tabular}

N, numbers of COVID-19 patient; SD, standard deviations.

However, neglecting the disease category of RADs or the grade of disease activity may affect the clinical significance of studies. Then, personalized medicine was highlighted again for the occurrence of some unexpected circumstances, such as the adverse events of HCQ, which showed a large heterogeneity; and the conventional dose of HCQ used for RADs was not applicable for the therapy of COVID-19 infection (79), which will certainly need to be adjusted on a case-by-case basis. Importantly, these conditions occur not only in the use of HCQ but also in other immune-mediated therapies. Also, because of the emergency situation of the COVID-19 pandemic, the observation periods of most studies were not long enough. Previous treatment exposure needs to be taken into account when evaluating clinical efficacy, cumulative effects or overlapping effects of drugs cannot be ruled out. As for the biologic agents, only the efficacy of tocilizumab has been suggested in meta-analyses, whereas, the efficacy of TNF inhibitors has been reported in only a few cohort studies and has not yet been supported by high-level evidence.

Each RAD has its characteristic pathogenesis, the immune pathways involved are not completely consistent. As mentioned earlier, autoantibodies can also present in some severe COVID19 patients with non-rheumatic disease, which may confuse physicians, especially non-rheumatoid specialists, in their assessment of the patient's primary disease. Therefore, the clinical diagnosis of rheumatic autoimmune diseases must be carried out with a rigorous attitude in the context of the epidemic.

There are limitations in this study. First, this study is not a systematic review, rigorous verification of the quality of the included literature is also necessary. Selection bias is inevitable, studies with statistically positive results are more likely to be published, which may obscure the clinical significance of the negative results. Additionally, there may also be bias in the 
quality control of the included literature. In this article, single case reports or studies without complete information were excluded. Unfortunately, prospective studies are still scarce. Existing retrospective articles or case series are either not large enough in sample size or did not address a specific topic of RADs. In these studies, due to the differences in design and analysis, the influence of heterogeneity on the results cannot be disregarded. Based on the collection of more data, our subsequent studies will continue to address the limitations of this study.

In conclusion, RADs patients are experiencing unprecedented challenges in COVID-19 epidemic. The incidence of COVID19 in RADs patients is not necessarily increased, which needs to be further, confirmed by more global data. Because RADs are commonly seen in females, elderly, and patients with

\section{REFERENCES}

1. Ferri C, Giuggioli D, Raimondo V, L'Andolina M, Tavoni A, Cecchetti $\mathrm{R}$, et al. COVID-19 and rheumatic autoimmune systemic diseases: report of a large Italian patients series. Clinical Rheumatol. (2020) 39:3195204. doi: 10.1007/s10067-020-05334-7

2. Zhong J, Shen G, Yang H, Huang A, Chen X, Dong L, et al. COVID19 in patients with rheumatic disease in Hubei province, China: a multicentre retrospective observational study. Lancet Rheumatol. (2020) 2:e557-64. doi: 10.1016/S2665-9913(20)30227-7

3. Pablos JL, Abasolo L, Alvaro-Gracia JM, Alvaro-Gracia. JM, Blanco. FJ, Blanco. R, et al. Prevalence of hospital PCR-confirmed COVID-19 cases in patients with chronic inflammatory and autoimmune rheumatic diseases. Ann Rheum Dis. (2020) 79:1170-3. doi: 10.1136/annrheumdis-2020-217763

4. Vázquez-Díaz $M$, Freites Nuñez DD, Leon L. Risk factors for hospital admissions related to COVID-19 in patients with autoimmune inflammatory rheumatic diseases. Rheumatol Int. (2020) 79:1393-9. doi: 10.1136/annrheumdis-2020-217984

5. Sarzi-Puttini P, Marotto D, Caporali R, Montecucco CM, Favalli EG, Franceschini F, et al. Prevalence of COVID infections in a population of rheumatic patients from Lombardy and Marche treated with biological drugs or small molecules: a multicentre retrospective study. J Autoimmun. (2021) 116:102545. doi: 10.1016/j.jaut.2020.102545

6. Fernandez-Ruiz R, Masson M, Kim MY, Myers B, Haberman RH, Castillo R, et al. Leveraging the United States epicenter to provide insights on COVID19 in patients with systemic lupus erythematosus. Arthritis Rheumatol. (2020) 72:1971-80. doi: 10.1002/art.41450

7. Gendebien Z, von Frenckell C, Ribbens C, André B, Thys M, Gangolf M, et al. Systematic analysis of COVID-19 infection and symptoms in a systemic lupus erythematosus population: correlation with disease characteristics, hydroxychloroquine use and immunosuppressive treatments. Ann Rheum Dis. (2020) 80:e94. doi: 10.1136/annrheumdis-2020-218244

8. He F, Luo Q, Lei M, Fan L, Shao X, Hu K, et al. Successful recovery of recurrence of positive SARS-CoV-2 RNA in COVID-19 patient with systemic lupus erythematosus: a case report and review. Clin Rheumatol. (2020) 39:2803-10. doi: 10.1007/s10067-020-05230-0

9. Rossotti R, Travi G, Ughi N, Corradin M, Baiguera C, Fumagalli R, et al. Safety and efficacy of anti-il6-receptor tocilizumab use in severe and critical patients affected by coronavirus disease 2019: a comparative analysis. J Infect. (2020) 81:e11-7. doi: 10.1016/j.jinf.2020.07.008

10. Misra DP, Agarwal V, Gasparyan AY, Zimba O. Rheumatologists' perspective on coronavirus disease 19 (COVID-19) and potential therapeutic targets. Clin Rheumatol. (2020) 39:2055-62. doi: 10.1007/s10067-020-05073-9

11. Peach E, Rutter M, Lanyon P, Grainge MJ, Hubbard R, Aston J, et al. Risk of death among people with rare autoimmune diseases compared to the general population in England during the 2020. COVID-19 pandemic. Rheumatology. (2020) 60:eaa855. doi: 10.1101/2020.10.09.20210237 comorbidities, the effect of these conditions on COVID-19 should not be ignored. The use of biologic agents such as TNFinhibitors or IL-6 receptor antagonists appears to be clinically beneficial, but more evidence is needed. In addition, some inflammatory markers that are routinely used to evaluate RADs may also be useful for disease surveillance in COVID-19.

\section{AUTHOR CONTRIBUTIONS}

LD and JZ are responsible for the study topic selection and the revision of manuscripts. YZ is responsible for investigation, data processing, and original draft writing. All authors contributed to the article and approved the submitted version.

12. Cordtz R, Lindhardsen J, Soussi BG, Vela J, Uhrenholt L, Westermann R, et al. Incidence and severeness of COVID-19 hospitalisation in patients with inflammatory rheumatic disease: a nationwide cohort study from Denmark. Rheumatology. (2020). doi: 10.1093/rheumatology/keaa897. [Epub ahead of print].

13. Murray K, Quinn S, Turk M, O’Rourke A, Molloy E, O’Neill L, et al. COVID19 and rheumatic musculoskeletal disease patients: infection rates, attitudes and medication adherence in an Irish population. Rheumatology. (2020) 60:902-6. doi: 10.1093/rheumatology/keaa694

14. Zen M, Fuzzi E, Astorri D, Saccon F, Padoan R, Ienna L, et al. SARSCoV-2 infection in patients with autoimmune rheumatic diseases in northeast Italy: a cross-sectional study on 916 patients. J Autoimmun. (2020) 112:102502. doi: 10.1016/j.jaut.2020.102502

15. Rongrong Pang, Jun Zhao, Zhenhua Gan, Zhiliang Hu, Xiang Xue, Yangjun $\mathrm{Wu}$, et al. Evolution of COVID-19 in patients with autoimmune rheumatic diseases. Aging. (2020) 12:9. doi: 10.18632/aging.202193

16. D'Silva KM, Serling-Boyd N, Wallwork R, Hsu T, Fu X, Gravallese $\mathrm{EM}$, et al. Clinical characteristics and outcomes of patients with coronavirus disease 2019. (COVID-19) and rheumatic disease: a comparative cohort study from a US 'hot spot'. Ann Rheum Dis. (2020) 79:1156-62. doi: 10.1136/annrheumdis-2020-217888

17. Ye C, Cai S, Shen G, Guan H, Zhou L, Hu Y, et al. Clinical features of rheumatic patients infected with COVID-19 in Wuhan, China. Ann Rheum Dis. (2020) 79:1007-13. doi: 10.1136/annrheumdis-2020-217627

18. Nuño L, Novella Navarro M, Bonilla G, Franco-Gómez K, Aguado P, Peiteado $\mathrm{D}$, et al. Clinical course, severity and mortality in a cohort of patients with COVID-19 with rheumatic diseases. Ann Rheum Dis. (2020) 79:165961. doi: 10.1136/annrheumdis-2020-218054

19. Moradi S, Masoumi M, Mohammadi S, Vafaeimanesh J, Mohseni M, Mahdavi $\mathrm{H}$, et al. Prevalence of coronavirus disease 2019 in rheumatic patients and evaluation of the effect of disease-modifying anti-rheumatic drugs. Intern Emerg Med. (2020) 16:919-23. doi: 10.21203/rs.3.rs-44445/v1

20. Tan EH, Sena AG, Prats-Uribe A, You SC, Ahmed WU, Kostka K, et al. COVID-19 in patients with autoimmune diseases: characteristics and outcomes in a multinational network of cohorts across three countries. Rheumatology. (2021) keab250. doi: 10.1093/rheumatology/keab250

21. Katz J. Prevalence of dry mouth in COVID-19 patients with and without Sicca syndrome in a large hospital center. Ir J Med Sci. (2021):13. doi: 10.1007/s11845-020-02480-4

22. Scirè CA, Carrara G, Zanetti A, Landolfi G, Chighizola C, Alunno A, et al. COVID-19 in rheumatic diseases in Italy: first results from the Italian registry of the Italian Society for Rheumatology (CONTROL-19). Clin Exp Rheumatol. (2020) 38:748-53.

23. Tiendrébéogo WJS, Kaboré F, Ntsiba H, Montero F. Coronavirus disease 2019. (COVID-19) in autoimmune and inflammatory conditions: clinical characteristics of poor outcomes. Clin Rheumatol. (2020) 40:1593-8. doi: 10.1007/s00296-020-04676-4 
24. Galarza-Delgado DA, Serna-Pena G, Compean-Villegas JE, Cardenasde la Garza JA, Pineda-Sic RA, Colunga-Pedraza IJ, et al. Characteristics and evolution of 38 patients with rheumatic diseases and COVID-19 under DMARD therapy. Clin Rheumatol. (2020) 40:1197-9. doi: 10.1007/s10067-020-05510-9

25. Gianfrancesco M, Hyrich KL, Al-Adely S, Carmona L, Danila MI, Gossec L. Characteristics associated with hospitalisation for COVID19 in people with rheumatic disease: data from the COVID-19 global rheumatology alliance physician-reported registry. Rheumatol Int. (2020) 79:859-66. doi: 10.1136/annrheumdis-2020-217871

26. Gokhale Y, Patankar A, Holla U, Shilke M, Kalekar L, Karnik ND, et al. Dermatomyositis during COVID-19 pandemic (a case series): is there a cause effect relationship? J Assoc Physicians India. (2020) 68:20-4.

27. Tariq S, Van Eeden C, Tervaert JWC, Osman MS. COVID-19, rheumatic diseases and immune dysregulation-a perspective. Clin Rheumatol. (2021) 40:433-42. doi: 10.1007/s10067-020-05529-y

28. Pablos JL. Clinical outcomes of hospitalised patients with COVID19 and chronic inflammatory and autoimmune rheumatic diseases: a multicentric matched cohort study. Cells. (2020) 79:1544-9. doi: 10.1136/annrheumdis-2020-218296

29. Ji W, Huh K, Kang M, Hong J, Bae GH, Lee R, et al. Effect of underlying comorbidities on the infection and severity of COVID-19 in Korea: a nationwide case-control study. J Korean Med Sci. (2020) 35:e237. doi: 10.3346/jkms.2020.35.e237

30. Haberman RH, Castillo R, Chen A, Yan D, Ramirez D, Sekar V, et al. COVID19 in patients with inflammatory arthritis: a prospective study on the effects of comorbidities and disease-modifying antirheumatic drugs on clinical outcomes. Arthritis Rheumatol. (2020) 72:1981-9. doi: 10.1002/art.41456

31. Arleo T, Tong D, Shabto J, O'Keefe G, Khosroshahi A. Clinical course and outcomes of COVID-19 in rheumatic disease patients: a case cohort study with a diverse population. Clin Rheumatol. (2021) 40:263342. doi: 10.1007/s10067-021-05578-X

32. Brito-Zerón P, Melchor S, Seror R, Priori R, Solans R, Kostov B, et al. SARS-CoV-2 infection in patients with primary Sjögren syndrome: characterization and outcomes of 51 patients. Rheumatology. (2020) 60:294657. doi: 10.1093/rheumatology/keaa748

33. Price CC, Altice FL, Shyr Y, Koff A, Pischel L, Goshua G, et al. Tocilizumab treatment for cytokine release syndrome in hospitalized patients with coronavirus disease 2019: survival and clinical outcomes. Chest. (2020) 158:1397-408. doi: 10.1016/j.chest.2020.06.006

34. Wallace B, Washer L, Marder W, Kahlenberg JM. Patients with lupus with COVID-19: University of Michigan experience. Ann Rheum Dis. (2020) 80:e35. doi: 10.1136/annrheumdis-2020-217794

35. Gianfrancesco MA, Leykina LA, Izadi Z, Taylor T, Sparks JA, Harrison C, et al. Association of race and ethnicity with COVID-19 outcomes in rheumatic disease: data from the COVID-19 global rheumatology alliance physician registry. Arthritis Rheumatol. (2020) 73:374-80. doi: 10.1002/art.41567

36. Akiyama S, Hamdeh S, Micic D, Sakuraba A. Prevalence and clinical outcomes of COVID-19 in patients with autoimmune diseases: a systematic review and meta-analysis. Ann Rheum Dis. (2020). doi: 10.1136/annrheumdis-2020-219337

37. Mehta B, Jannat-Khah D, Mancuso CA, Bass AR, Moezinia CJ, Gibofsky A, et al. Geographical variations in COVID-19 perceptions and patient management: a national survey of rheumatologists. Semin Arthritis Rheum. (2020) 50:1049-54. doi: 10.1016/j.semarthrit.2020.06.017

38. Haberman R, Axelrad J, Chen A, Castillo R, Yan D, Izmirly P, et al. Covid-19 in immune-mediated inflammatory diseases - case series from New York. $N$ Engl J Med. (2020) 83:85-8. doi: 10.1056/NEJMc2009567

39. Kichloo A, Aljadah M, Albosta M, Wani F, Singh J, Solanki S. COVID-19 and acute lupus pneumonitis: diagnostic and treatment dilemma. J Investig Med High Impact Case Rep. (2020) 8. doi: 10.1177/2324709620933438. [Epub ahead of print].

40. Alharthy A, Faqihi F, Nasim N, Noor A, Akhtar S, Balshi A, et al. COVID-19 in a patient with a flare of systemic lupus erythematosus: a rare case-report. Respir Med Case Rep. (2020) 31:101252. doi: 10.1016/j.rmcr.2020.101252

41. Favalli EG, Bugatti S, Klersy C, Biggioggero M, Rossi S, De Lucia O, et al. Impact of corticosteroids and immunosuppressive therapies on symptomatic
SARS-CoV-2 infection in a large cohort of patients with chronic inflammatory arthritis. Arthritis Res Ther. (2020) 22:290. doi: 10.1186/s13075-020-02395-6

42. Cavagna L, Seminari E, Zanframundo G, Gregorini M, Di Matteo A, Rampino $\mathrm{T}$, et al. Calcineurin inhibitor-based immunosuppression and COVID19: results from a multidisciplinary cohort of patients in northern Italy. Microorganisms. (2020) 8:977. doi: 10.3390/microorganisms 8070977

43. Hariyanto TI, Halim DA, Jodhinata C, Yanto TA, Kurniawan A. Colchicine treatment can improve outcomes of coronavirus disease 2019 (COVID-19): a systematic review and meta-analysis. Clin Exp Pharmacol Physiol. (2021). 48:823-30. doi: 10.1111/1440-1681.13488

44. Lane JCE, Weaver J, Kostka K, Duarte-Salles T, Abrahao MTF, Alghoul H, et al. Risk of hydroxychloroquine alone and in combination with azithromycin in the treatment of rheumatoid arthritis: a multinational, retrospective study. $J$ Korean Med Sci. (2020) 2:e698-711. doi: 10.1016/S2665-9913(20)30276-9

45. Ghazawi FM, Lim M, Dutz JP, Kirchhof MG. Infection risk of dermatologic therapeutics during the COVID-19 pandemic: an evidence-based recalibration. Int J Dermatol. (2020) 59:1043-56. doi: 10.1111/ijd.15028

46. Lu C, Li S, Liu Y. Role of immunosuppressive therapy in rheumatic diseases concurrent with COVID-19. Ann Rheum Dis. (2020) 79:7379. doi: 10.1136/annrheumdis-2020-217460

47. Rainsford KD, Parke AL, Clifford-Rashotte M, Kean WF. Therapy and pharmacological properties of hydroxychloroquine and chloroquine in treatment of systemic lupus erythematosus, rheumatoid arthritis and related diseases. Inflammopharmacology. (2015) 23:231-69. doi: 10.1007/s10787-015-0239-y

48. Ferreira A, Oliveira ESA, Bettencourt P. Chronic treatment with hydroxychloroquine and SARS-CoV-2 infection. J Med Virol. (2021) 93:755-9. doi: 10.1002/jmv.26286

49. Mathian A, Mahevas M, Rohmer J, Roumier M, Cohen-Aubart F, AmadorBorrero B, et al. Clinical course of coronavirus disease 2019 (COVID-19) in a series of 17 patients with systemic lupus erythematosus under longterm treatment with hydroxychloroquine. Ann Rheum Dis. (2020). 79:8379. doi: 10.1136/annrheumdis-2020-217566

50. Ulrich RJ, Troxel AB, Carmody E, Eapen J, Backer M, DeHovitz JA, et al. Treating COVID-19 with hydroxychloroquine (TEACH): a multicenter, double-blind randomized controlled trial in hospitalized patients. Open Forum infect Dis. (2020) 7:ofaa446. doi: 10.1093/ofid/ofaa446

51. Teh CL, Cheong YK, Wan Musa WR, Wan Mohd Akbar SA, Mat Husin N, Gun SC. COVID-19 among Malaysian patients with systemic lupus erythematosus on hydroxychloroquine. Ann Rheum Dis. (2020) 80:e69. doi: 10.1136/annrheumdis-2020-218154

52. Littlejohn E. Keeping lupus patients on hydroxychloroquine during the COVID-19 pandemic. Cleve Clin J Med. (2020). doi: 10.3949/ccjm.87a.ccc023. [Epub ahead of print].

53. Goldman A, Bomze D, Dankner R, Hod H, Meirson T, Boursi B, et al Cardiovascular adverse events associated with hydroxychloroquine and chloroquine: a comprehensive pharmacovigilance analysis of pre-COVID-19 reports. Br J Clin Pharmacol. (2020) 87:1432-42. doi: 10.1111/bcp.14546

54. Chen Z, Hu J, Zhang Z, Jiang S, Han S, Yan D, et al. Efficacy of hydroxychloroquine in patients with COVID-19: results of a randomized clinical trial. Epidemiology. (2020). doi: 10.1101/2020.03.22.20040758

55. Doyno C, Sobieraj DM, Baker WL. Toxicity of chloroquine and hydroxychloroquine following therapeutic use or overdose. Clin Toxicol. (2021) 59:12-23. doi: 10.1080/15563650.2020.1817479

56. Nagaraja BS, Ramesh KN, Dhar D, Mondal MS, Dey T, Saha S, et al. HyPE study: hydroxychloroquine prophylaxis-related adverse events' analysis among healthcare workers during COVID-19 pandemic: a rising public health concern. J Public Health. (2020) 42:493-503. doi: 10.1093/pubmed/fdaa074

57. Ahmadinejad Z, Assari R, Ayoobi Yazdi N, Mazloomi SH, Javanshayani P, Khalili Afousi H, et al. COVID-19 pandemic and biological therapy in rheumatologic disorders: how to deal with?. Reumatismo. (2020) 72:1737. doi: 10.4081/reumatismo.2020.1289

58. Sharmeen S, Elghawy A, Zarlasht F, Yao Q. COVID-19 in rheumatic disease patients on immunosuppressive agents. Semin Arthritis Rheum. (2020) 50:680-6. doi: 10.1016/j.semarthrit.2020.05.010

59. Ikonomidis I, Pavlidis G, Katsimbri P, Lambadiari V, Parissis J, Andreadou I, et al. Tocilizumab improves oxidative stress and endothelial glycocalyx: a 
mechanism that may explain the effects of biological treatment on COVID-19. Food Chem Toxicol. (2020) 145:111694. doi: 10.1016/j.fct.2020.111694

60. Rossi B, Nguyen LS, Zimmermann P, Boucenna F, Dubret L, Baucher L, et al. Effect of tocilizumab in hospitalized patients with severe COVID19 pneumonia: a case-control cohort study. Pharmaceuticals. (2020) 13:317. doi: 10.3390/ph13100317

61. Hariyanto TI, Hardyson W, Kurniawan A. Efficacy and safety of tocilizumab for coronavirus disease 2019 (Covid-19) patients: a systematic review and meta-analysis. Drug Res. (2021) 71:265-74. doi: 10.1055/a-1336-2371

62. Ivan Hariyanto T, Kurniawan A. Tocilizumab administration is associated with the reduction in biomarkers of coronavirus disease 2019 infection. J Med Virol. (2021) 93:1832-6. doi: 10.1002/jmv.26698

63. Colaneri M, Bogliolo L, Valsecchi P, Sacchi P, Zuccaro V, Brandolino F, et al. Tocilizumab for treatment of severe COVID-19 patients: preliminary results from SMAtteo COvid19 REgistry (SMACORE). Microorganisms. (2020) 8:695. doi: 10.3390/microorganisms8050695

64. Alarfaj HF, Alarfaj AS, Loarce-Martos J. High rates of severe disease and death due to SARS-CoV-2 infection in rheumatic disease patients treated with rituximab: a descriptive study. Int J Rheum Dis. (2020) 40:201521. doi: 10.1007/s00296-020-04699-x

65. Tan C, Huang Y, Shi F, Tan K, Ma Q, Chen Y, et al. C-reactive protein correlates with computed tomographic findings and predicts severe COVID-19 early. $J$ Med Virol. (2020) 92:856-62. doi: 10.1002/jmv.25871

66. Ruan Q, Yang K, Wang W, Jiang L, Song J. Clinical predictors of mortality due to COVID-19 based on an analysis of data of 150 patients from Wuhan, China. Intens Care Med. (2020) 46:846-8. doi: 10.1007/s00134-020-05991-x

67. Zhou F, Yu T, Du R, Fan G, Liu Y, Liu Z, et al. Clinical course and risk factors for mortality of adult inpatients with COVID-19 in Wuhan, China: a retrospective cohort study. Lancet. (2020) 395:105462. doi: 10.1016/S0140-6736(20)30566-3

68. Hariyanto TI, Japar KV, Kwenandar F, Damay V, Siregar JI, Lugito NPH, et al. Inflammatory and hematologic markers as predictors of severe outcomes in COVID-19 infection: a systematic review and meta-analysis. Am J Emerg Med. (2021) 41:110-9. doi: 10.1016/j.ajem.2020.12.076

69. Qin C, Zhou L, Hu Z, Zhang S, Yang S, Tao Y, et al. Dysregulation of immune response in patients with coronavirus 2019 (COVID-19) in Wuhan, China. Clin Infect Dis. (2020) 71:762-8. doi: 10.1093/cid/ciaa248

70. Firizal AS, Sugianli AK, Hamijoyo L. Cut off point of neutrophilto-lymphocyte ratio as a marker of active disease in systemic lupus erythematosus. Lupus. (2020) 29:1566-70. doi: 10.1177/0961203320950822

71. Reyes Gil M, Barouqa M, Szymanski J, Gonzalez-Lugo JD, Rahman $\mathrm{S}$, Billett HH. Assessment of lupus anticoagulant positivity in patients with coronavirus disease 2019 (COVID-19). JAMA Netw Open. (2020) 3:e2017539. doi: 10.1001/jamanetworkopen.2020.17539

72. Bowles L, Platton S. Lupus anticoagulant and abnormal coagulation tests in patients with Covid-19. N Engl J Med. (2020) 383:28890. doi: $10.1056 / \mathrm{NEJMc} 2013656$

73. Bertin D, Brodovitch A, Beziane A, Hug S, Bouamri A, Mege JL, et al. Anticardiolipin IgG autoantibody level is an independent risk factor for COVID-19 severity. Arthritis Rheumatol. (2020) 72:1953-5. doi: 10.1002/art.41409

74. Vlachoyiannopoulos PG, Magira E, Alexopoulos H, Jahaj E, Theophilopoulou $\mathrm{K}$, Kotanidou A, et al. Autoantibodies related to systemic autoimmune rheumatic diseases in severely ill patients with COVID-19. Ann Rheum Dis. (2020) 79:1661-3. doi: 10.1136/annrheumdis-2020-2 18009

75. Zhou Y, Han T, Chen J, Hou C, Hua L, He S, et al. Clinical and autoimmune characteristics of severe and critical cases of COVID-19. Clin Transl Sci. (2020) 13:1077-86. doi: 10.1111/cts.12805

76. Pascolini S, Vannini A, Deleonardi G, Ciordinik M, Sensoli A, Carletti I, et al. COVID-19 and immunological dysregulation: can autoantibodies be useful? Clin Transl Sci. (2021) 14:502-8. doi: 10.1111/cts.12908

77. Fujii H, Tsuji T, Yuba T, Tanaka S, Suga Y, Matsuyama A, et al. High levels of anti-SSA/Ro antibodies in COVID-19 patients with severe respiratory failure: a case-based review: high levels of anti-SSA/Ro antibodies in COVID-19. Clin Rheumatol. (2020) 39:3171-5. doi: 10.1007/s10067-020-05359-y

78. Guan WJ, Ni ZY, Hu Y, Liang WH, Ou CQ, He JX, et al. Clinical characteristics of coronavirus disease 2019 in China. N Engl J Med. (2020) 382:170820. doi: 10.1056/NEJMoa2002032

79. Jung SY, Kim MS, Kim MC, Choi SH, Chung JW, Choi ST. Effect of hydroxychloroquine pre-exposure on infection with SARS-CoV-2 in rheumatic disease patients: a population-based cohort study. Clin Microbiol Infect. (2020) 27:611-7. doi: 10.1016/j.cmi.2020.12.003

80. Emmi G, Bettiol A, Mattioli I, Silvestri E, Di Scala G, Urban ML, et al. SARS-CoV-2 infection among patients with systemic autoimmune diseases. Autoimmun Rev. (2020) 19:102575. doi: 10.1016/j.autrev.2020.102575

81. Yousaf A, Gayam S, Feldman S, Zinn Z, Kolodney M. Clinical outcomes of COVID-19 in patients taking tumor necrosis factor inhibitors or methotrexate: a multicenter research network study. J Am Acad Dermatol. (2021) 84:70-5. doi: 10.1016/j.jaad.2020.09.009

Conflict of Interest: The authors declare that the research was conducted in the absence of any commercial or financial relationships that could be construed as a potential conflict of interest.

Publisher's Note: All claims expressed in this article are solely those of the authors and do not necessarily represent those of their affiliated organizations, or those of the publisher, the editors and the reviewers. Any product that may be evaluated in this article, or claim that may be made by its manufacturer, is not guaranteed or endorsed by the publisher.

Copyright $\odot 2021$ Zhu, Zhong and Dong. This is an open-access article distributed under the terms of the Creative Commons Attribution License (CC BY). The use, distribution or reproduction in other forums is permitted, provided the original author(s) and the copyright owner(s) are credited and that the original publication in this journal is cited, in accordance with accepted academic practice. No use, distribution or reproduction is permitted which does not comply with these terms. 